\title{
Anjos da Meia Noite: Work, leisure and rights in the Rio de Janeiro of the First Republic
}

\author{
Leonardo Affonso de Miranda Pereira[1]
}

\begin{abstract}
In July 1913, the members of the Family Dancing Club Anjos da Meia Noite required a habeas corpus to the Supreme Court to secure their right to perform dancing parties in the port area of Rio de Janeiro. It was the end of a long legal battle, through which the low-income workers who were part of the club, mostly the Blacks and Mestizos, tried to maintain their recreational rights. They did so, however, from a kind of association whose objectives were far from the logic of the labor movement at the time. Tracking the case, analyzing its background and logic, is a way of reflecting on the passive image projected on the Rio de Janeiro's workers of the First Republic by the historiography.
\end{abstract}

Keywords: workers; leisure; citizenship.

Os Anjos da Meia-Noite: trabalhadores, lazer e direitos no Rio de Janeiro da Primeira República

\section{Resumo}

Em julho de 1913, os sócios do Club Dançante Familiar Anjos da Meia Noite requeriam ao Supremo Tribunal Federal um habeas corpus que lhes garantisse o direito de realizar bailes dançantes na região portuária do Rio de Janeiro. Era o fim de uma longa batalha jurídica por meio da qual os trabalhadores de baixa renda que compunham o clube, em sua maioria negros e mestiços, tentavam assegurar seus direitos recreativos. O faziam, porém, a partir de um tipo de associação cujos objetivos estavam distantes da lógica própria ao movimento operário do período. Acompanhar o caso, dando a ver seus antecedentes e lógicas, é, por isso, um meio de refletir sobre a imagem passiva projetada sobre os trabalhadores do Rio de Janeiro na Primeira República por parte da historiografia. Palavras-chave: trabalhadores; lazer; cidadania.

Los Anjos da Meia Noite: trabajadores, ocio y derechos en Río de Janeiro de la Primera República

\section{Resumen}

En julio del año 1913, los miembros del Club de Baile Familiar Anjos da Meia Noite presentaron a la Corte Suprema un recurso de habeas corpus que les garantizaba el derecho de realizar sus bailes en la zona portuaria de Río de Janeiro. Era el final de una larga batalla legal en que los trabajadores de bajos ingresos del club, en su mayoría negros y mestizos, trataron de proteger sus derechos al entretenimiento. Lo hicieron, sin embargo, en una asociación cuyos objetivos estaban lejos de la lógica del movimiento obrero de la época. Analizar el caso, mostrando su lógica, es por lo tanto una manera de reflexionar sobre la imagen pasiva de los trabajadores del Rio de Janeiro de la Primera República proyectada por parte de la historiografía.

Palabras clave: trabajadores; ocio; ciudadanía.

\section{Les Anges de Minuit: le travail, les loisirs et les droits au Rio de Janeiro de la Première République}

\section{Résumé}

En Juillet 1913, les membres duClub de Danse delaFamilie Les Anges de Minuit ont demandéà la Cour suprême un habeas corpus pour leurgarantirle droità exécuter des danses dans la zone portuaire du Rio de Janeiro. Cétait la fin d'une longue bataille juridique menée par les travailleurs à faible revenu qui ont participé au club, surtout les noirs et les métis, pour assurer leur droits à les loisirs. Cela a été fait à partir d'une sorte dassociation dont les objectifs étaient distants dela logique du mouvement ouvrier de lépoque.Suivrelaffaire, en expliquant son origine et sa logique, c'est une façon de réfléchir sur limage passive qui est resté des travailleurs de Rio de Janeiro dans la Première République du point de vue de l'historiographie.

Mots-clés: travailleurs; les loisirs; citoyenneté. 
$\mathrm{O}$ n July 5, 1913, the Brazilian Federal Supreme Court received a different lawsuit in relation to those that usually arrived to the highest Court in the country. The lawyer of the associates of the Family Dancing Club Anjos de Meia Noite (Midnight Angels), required a habeas corpus that could secure their right to continue to organize balls and other recreational activities in Saúde, the port region of Rio de Janeiro. Facing a situation in which the club would be "violently impelled not to work by the Chief of Police", since he had its headquarters closed and annulled its license of operation, they claimed that, with the prohibition, the club would "cease to exist", being "extinct and dissolved". Supported by the Law established in 1893 to regulate "the organizations or associations founded with religious, moral, scientific, artistic, political or recreational purposes", which recognized the possibility of a juridical personality of such associations, ${ }^{2}$ they presented themselves to the court to defend the survival and the freedom of the club.

It was an unexpected activity even for the contemporaries, defined by the newspaper $A$ Noite as "an original request". ${ }^{3}$ The first reason why it was strange was the fact that the solicitant of a habeas corpus was not a natural person, whose freedom or life was being threatened, but a civil society. But this was not the only reason for the unusual aspect of this request. Together with the matters connected to the procedural rules, the case proved to be unique because of the profile of the solicitant, a mere recreational club. Founded on July $1^{\text {st }}, 1906$, according to its statutes, its objective was to "throw dance balls, at least once a month to its associates, guests and family members"; "teach its associates how to dance", "conduct dance lessons for its associates"; and "to entertain, by moral and licit means". Except for providing for the simple search of pleasure and fun to its members, the club did not have any other purpose such as social representation or political struggle. Thus the case was very abnormal as it kept its distance from the matters usually analyzed in the country's Supreme Court.

Finally, a third issue would explain the surprise of the contemporaries before the request was taken to the Supreme Court by the associates of Anjos da Noite: the social and ethnical profile of its components. This is demonstrated by the professions of its directors, informed to the Chief of Police in 1912, at the time when the club requested for the annual license of operation. Their professions were: one tile-layer, one worker from the Marine's arsenal, one employee of the light company and one dockworker from the pier, who was the president of the club. ${ }^{5}$ The type of activity of its founders was similar, among which it was possible to identify manual workers, such as Cesar Neves de Carvalho, a coachman, and David Francisco Carvalho, a stoker. ${ }^{6}$ Observing this socially defined composition, a writer from Jornal do Brasil, in one of the stories about Anjos

\footnotetext{
'Arquivo Nacional. Fundo Supremo Tribunal Federal (BV). BV.4624. - Série Habeas Corpus - Clube Dançante Familiar Anjos da Meia Noite (1913), fl.12.

2“Lei no 173, de 10 de Setembro de 1893”, In: Coleção de Leis do Brasil - 1893, vol. 1, p. 45. Disponível em: $<$ http://www2.camara.leg.br/legin/fed/lei/1824-1899/lei-173-10-setembro-1893-540973-publicacaooriginal42519-pl.html>. Acesso em: 15 out. 2013.

3“Um pedido original”, A Noite, 5 de julho de 1913.

4"Sociedades civis - Club Dançante Familiar Anjos da Meia Noite”, Diário Oficial, 10 de março de 1910, p. 1786. ${ }^{5}$ Arquivo Nacional, GIFI 6C 432.

${ }^{6}$ Cf. "Encontro de veículos", A Noite, 25 de julho de 1912; and "Centro Geral dos Foguistas", Correio da Manhã, 29 de março de 1904. The founders' name list can be found in the statutes "Sociedades civis - Club Dançante Familiar Anjos da Meia Noite", Diário Oficial, 10 de março de 1910, p. 1786.
} 
da Noite, defined them as a society "that gathers the elite of people who have fun with little money"?

In a society that had recently ended the slavery system, in which the Blacks and Mestizos still constituted most of the workforce, it is no surprise that most of the components of that group had African ascendancy. Far from being just a detail, such ethnical aspect was present in the identity built by the associates of the club. Not by chance, in the same year 1913, on the day to celebrate the 25 years of slavery abolition, its board published an ad in the newspapers publicizing "a great kermesse ball" to "celebrate the party of May 13" (date of the slavery abolition), organized after the "requests by the members of this club".

If such factors can explain why the contemporaries themselves thought the appeal presented by the associates to the Federal Supreme Court was strange, and such a request became even more incomprehensible when the incident became a part of the historiography of the period. From the 1930s on, intellectuals connected to the political project called Estado Novo (New State) began to define an oligarchic and excluding sign for the first decades of the Republican System, in which there would be no space of action or participation for the workers. ${ }^{9}$ By assuming the inability of the collective action of national workers, mostly due to their slave condition in the recent past, there was complete lack of political participation of workers during this period.

Crystalized by historiography in the following decades, being called República Velha (Old Republic), ${ }^{10}$ such analysis was repelled by more recent studies, which point to its teleological aspect. Still, in some analyses, the belief in the complete impossibility for the workers of the time to have any kind of political participation remains. In an article that recollects the arguments exposed in previous studies, José Murilo de Carvalho defends that, in the early $20^{\text {th }}$ century, "the oligarchies could invent and consolidate a power system which was able to manage its internal conflicts and put the people aside". ${ }^{11}$ From the political engineering formulated by Campos Salles and his policy of governors, a power system was fixed to ensure the stability of the republic, which excluded any possibility of citizenship for the workers.

As a result, the only chances people had of manifesting throughout the formative years of the Republican System would take place "to the margin of formal mechanisms of participation, if not against the political system itself". This is why labor strikes led by immigrant workers, whose effect over the political system "were limited" due to the difficulty that such movements could "influence politics through electoral participation", or in rebellions of "defensive character" promoted by a broader universe of poor workers: the "people of the streets", who would react with riots, such as the Vaccine Rebellion or the Revolt of the Lash (the former, popular rebellion that took place in 1904 against the mandatory smallpox vaccination; and the latter, rebellion of mariners in 1910 against corporal punishment in the Navy) considered them to be illegitimate

7“Quem não trouxe... - Depois do baile - Ciúme sanguinário", Jornal do Brasil, 26 de maio de 1913. 8“S.D.F. Anjos da Meia Noite", Jornal do Brasil, 13 de maio de 1913.

In this paragraph, I accompany the observations made by Ângela de Castro Gomes e Martha Abreu in the"Presentation" tothedossier "A Nova Velha República",Tempo, n. 26, jan. 2009, p. 1-14.

${ }^{10} \mathrm{Cf}$. Edgard Carone, A República Velha (Instituições e classes sociais), São Paulo, DIFEL, 1970.

"José Murilo de Carvalho, "Os três povos da República", Revista USP, n. 59, set.-nov. 2003, p. 96. See also, Idem, Os bestializados. O Rio de Janeiro e a República que não foi, São Paulo, Companhia das Letras, 1987. 
in their lives, by the interference of the State, Hence, only the people who were politically active were established due to the "inability of the system to incorporate the people from the streets". ${ }^{12}$

Being real for all of the workers, such exclusion would have been even more remarkable in the case of the Blacks and Mulattos, who would have been completely marginalized in that period due to their costumes and traditions, and they were the main targets of the republican surveillance. From the principles of the scientific logic, which began to justify all of the actions of the republican governments, ${ }^{13}$ these individuals would have turned into the favorite victims of the new system, since it tried to erase their presence from the image that was shown to the nation. In this scenario, they would only try to defensively react to this attempt of deletion/exclusion, with an attitude of resisting and showing their aversion to the new political order. ${ }^{14}$ The oligarchic and exclusive institutional order and the principles of a scientific ideology that justified such exclusion would define, in such analyses, the image of a White and cosmopolitan republican belle époque. ${ }^{15}$ It would have completely crushed the increasing aspirations of the former slaves and their descendants for their rights.

When analyzed from a purely electoral perspective, such readings are correct and demonstrate the way the Republican Order was structured from the point of view of those who commanded its mechanisms. Still, they forgot to consider the possibility of other forms of political participation, which would be formed inside this Republican Order. ${ }^{16}$ It is especially the case of those who adopted logics and ways of action that were different from the intellectual leaderships or the workers from Europe. After analyzing the case of many enslaved workers during the empire period, studies carried out from the 1980s on, showed the partiality of the analyses that saw the prisoners as mere objects, submissive to the will and action of the lords. Considering the experience of such individuals, analyses such as the ones by Sidney Chalhoub, João José Reis and Maria Helena Machado emphasized the logic itself, which fueled their actions daily. These analyses pointed out that, even if by different paths from those developed by the European workers, slaves and free colored men started their own

\footnotetext{
12José Murilo de Carvalho, "Os três povos da República", Revista USP, n. 59, set.-nov. 2003, p. 107-110. About the oligarchic logic of the policy of governos implemented by Campos Salles, see also Maria Efigênia Lage de Resende, "O processo político na Primeira República e o liberalismo oligárquico", In: Lucília de Almeida Delgado; Jorge Ferreira (orgs.), O tempo do liberalismo excludente. Da Proclamação da República à Revolução de 1930, Rio de Janeiro, Civilização Brasileira, 2003, p. 89-120.

${ }^{13}$ Cf. Oswaldo Porto Rocha, A Era das Demolições: cidade do Rio de Janeiro 1870-1920, Rio de Janeiro, Secretaria Municipal de Cultura, 1986; e Sidney Chalhoub, Cidade febril: cortiços e epidemias na Corte imperial, São Paulo, Cia da Letras, 1996.

${ }^{14}$ Check, forinstance, Nicolau Sevcenko, A Revolta da Vacina: mentes insanas em corpos rebeldes, São Paulo, Brasiliense, 1983; e Raquel Soihet, A subversão pelo riso, Rio de Janeiro, Fundação Getúlio Vargas, 1998.

${ }^{15} \mathrm{Cf}$. Jeffrey Needell, Belle Époque Tropical. Sociedade e cultura de elite no Rio de Janeiro na virada do século, São Paulo, Cia das Letras, 1993.

${ }^{16}$ In the words of Ângela de Castro Gomes and Martha Abreu, "we can state that it is still unknown, basically due to lack of studies, a rich movement of actors - intellectuals, workers, medium and popular classes - in the field of political participation, which reached varied designs and more or less formal in different institutions and associations", In: "Apresentação" ao dossiê "A Nova Velha República”, Tempo, n. 26, jan. 2009, p. 4.
} 


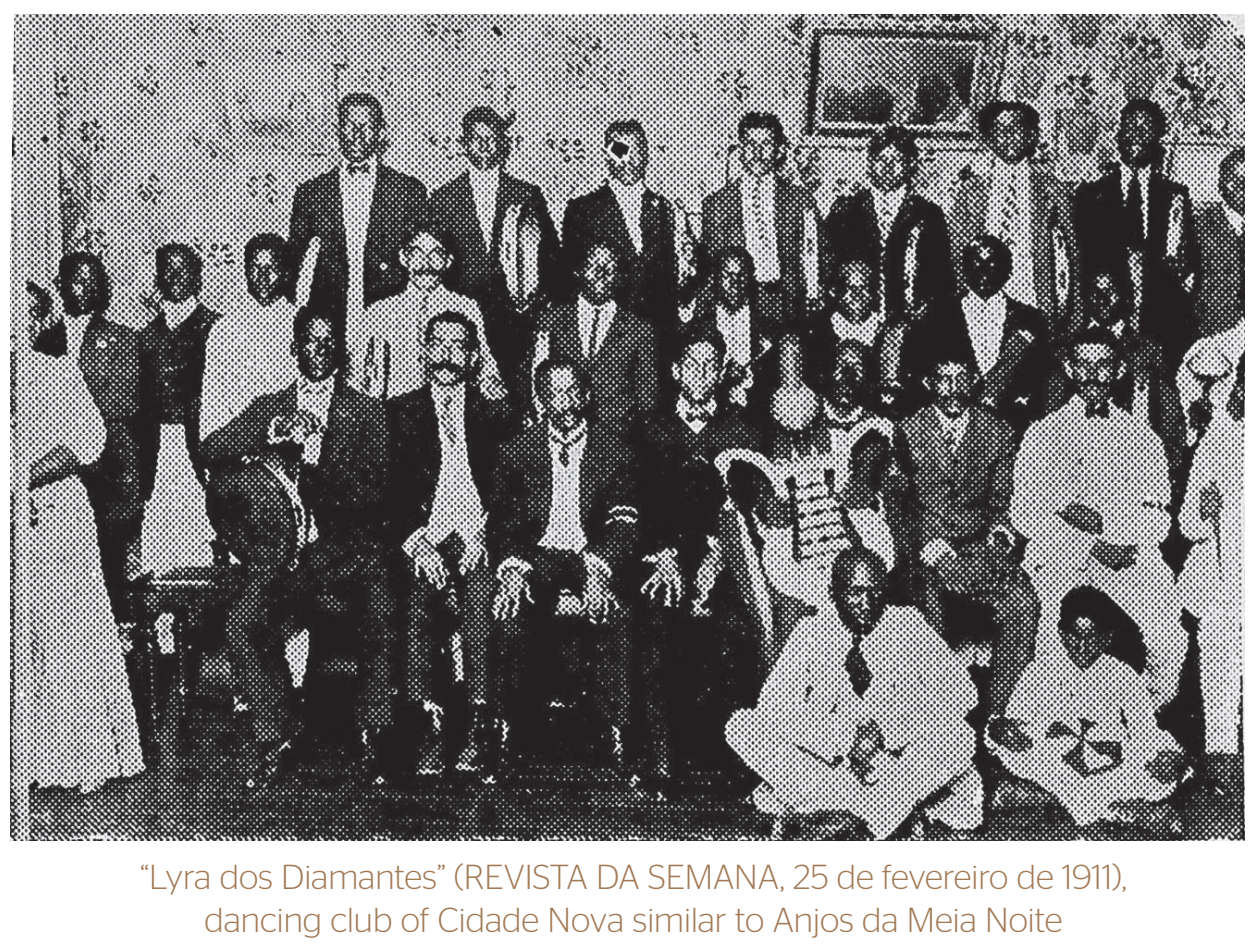

form of struggle, at times built inside the network of paternalism. ${ }^{17}$ Without considering the very own logic that encouraged these forms of struggle and articulation, the authors could only try to understand it in the early period of the Republican system and attributed a defensive posture to them, the simple denial of the New Order.

As a result, there was a deep gap in understanding the experiences of the Black and Mulatto workers during the end of the Empire (when the slaves and free men fought in many ways against the domination they were submitted to) and the $1930 \mathrm{~s}$ and the $20^{\text {th }}$ century, when their costumes and practices would finally be incorporated, at least formally, to the new configuration of nationality. Many of those who analyzed the creation of a new profile for the Brazilian culture from the late 1920s on ignored the very possibility of an agency of workers inside this process. They turned it into a mere result of the gift from Estado Novo or the "discovery" of the intellectuals, who then began to value this as a popular and mestizo mark of the nation ${ }^{18}$ - and such interpretation again placed the Black and Mulatto workers as mere supporting characters.

In an attempt to escape from such a trap, some studies pointed out the need for considering the importance of the costumes and practices shared by

\footnotetext{
${ }^{17}$ Check, among others, João José Reis; Eduardo Silva, Negociação e conflito: a resistência negra no Brasil escravista, São Paulo, Companhia das Letras, 1989; Sidney Chalhoub, Visões da Liberdade: uma história dos últimos anos da escravidão na Corte, São Paulo, Companhia das Letras, 1990; e Maria Helena P.T. Machado, O plano e o pânico, São Paulo/Rio de Janeiro, EDUSP/EDUERJ, 1994.

${ }^{18 S e e}$ for instance, José Adriano Fenerick, Nem do Morro Nem da Cidade: as transformações do samba e a indústria cultural. 1920-1945, São Paulo, Annablume, 2005 e Florencia Garramuño, Modernidades primitivas. Tango, samba e nación, Buenos Aires, Fondo de Cultura Económica, 2007.
} 
the Black men and women, as well as Mulattos, in this process in the previous decades. After seeing them as objects of interest in the intellectual world in the late $19^{\text {th }}$ century, ${ }^{19}$ these studies showed that the cultural practices of these African descendant workers were established as a way to see them as active subjects in this story. ${ }^{20}$ However, in general, these studies focused on matters that are far away from the reflection about their formal citizenship and political participation and turning them especially to recreational events, such as parties, songs and balls. If these activities would mean the strength and vitality of costumes and experiences that could serve as the base for the new nationality image that was established in the following decades, the role of such cultural practices against a political structure that was made to exclude the subjects by promoting them is yet to be understood.

After appealing to the Federal Supreme Court in the attempt to secure their recreational and association rights, the associates of Anjos da Meia Noite give us the chance to analyze, under a new perspective, the meaning of essential recreational costumes in the experience of men and women to whom it was common to deny any possibility of action. Studies as the one by Maria Cecília Velasco Cruz already show us how these workers, marked by the African ascendancy managed their own forms of political articulation in the beginning of the Republican system. This was expressed in the union disputes between dockworkers in Rio de Janeiro. ${ }^{21}$ It is important to explore the case of Anjos da Noite, with its history and logics, in order to try and understand how these individuals saw themselves as citizens - that is, the way they interacted with a new institutional order by means of their daily recreational practices. They tried to define their place in the Republican nation that emerged.

\section{In the sambas of Saúde}

When some residents of the Saúde neighborhood decided to found the Family Dancing Club, Anjos da Meia Noite, on July 1 ${ }^{\text {st }}, 1906$, they were far from being original. By February of the same year, at least 60 other similar groups had already received licenses of operation from the Chief of Police in the Federal District - and this number would get to 146, in 1912, showing the strength of

\footnotetext{
${ }^{19}$ Martha Abreu; Carolina Dantas, "Música popular, folclore e nação no Brasil, 1890-1920", In: José Murilo de Carvalho (org.), Nação e cidadania no Império: novos horizontes, Rio de Janeiro, Civilização Brasileira, 2007. p. 123-151; Antonio Herculano Lopes, “Vem cá mulata!”, Tempo, vol. 26, jan. 2009, p. 80-100; e Carolina Vianna Dantas, "A nação entre sambas, cordões e capoeiras nas primeiras décadas do século XX”, ArtCultura, vol. 13, 2011, p. 85-102.

${ }^{20} \mathrm{Cf}$. Tiago de Melo Gomes, "Para além da casa da Tia Ciata: outras experiências no universo cultural carioca (1830-1930)",Afro-Ásia, vol. 29-30, 2004, p. 175-198; Martha Abreu, "Sobre mulatas orgulhosas e crioulos atrevidos: conflitos raciais, gênero e nação nas canções populares (sudeste do Brasil, 1890-1920)", Tempo, vol. 16, Rio de Janeiro, 2004, p. 143-174; Maria Clementina Pereira Cunha, "Não me ponha no xadrez com esse malandrão".Conflitos e identidades entre sambistas no Rio de Janeiro, início do século XX",Afro-Ásia, vol. 38, 2009, p. 179-210; and Leonardo Pereira, "O Prazer das Morenas: bailes, ritmos e identidades nos clubes dançantes da Primeira República”, In: Andrea Marzano; Victor Andrade de Melo (orgs.), Vida Divertida: histórias do lazer no Rio de Janeiro (1830-1930), Rio de Janeiro, Apicuri, 2010, p. 275-299.

${ }^{21}$ Maria Cecília Velasco Cruz, "Da tutela ao contrato: 'homens de cor' brasileiros e o movimento operário carioca no pós-abolição", Topoi, vol. 11, n. 20, jan.jun. 2010, p. 114-135.
} 
dancing associations in the city. ${ }^{22}$ The founders of the association were only joining a phenomenon that started in the last decade of the $19^{\text {th }}$ century, and which had spread throughout the city in a few years: the dancing fever. "Rio de Janeiro is the city of dance", said the poet Olavo Bilac in a chronicle published in the prestigious magazine Kosmos, few weeks before its foundation. ${ }^{23}$ Surprised by the proliferation of dancing clubs in all of the neighborhoods of the federal capital, he was astonished about the excitement caused by this phenomenon which turned dancing in the city "into more than a costume or entertainment: it is a passion, an addiction, a fever".

Even if he wanted to state the excitement about dancing as "a characteristic concern of the life in Rio de Janeiro", Olavo Bilac still presented the peculiarities of the way it was lived by the different individuals. For him, "by studying and classifying the favorite dances of the people, per neighborhood", it would be possible to "establish the moral geography of the town". "Botafogo does not dance like Catumbi, Tijuca does not dance like Saúde", he explained that "each neighborhood has its own dance, which is its characteristic, rigorous and unmistakable physiognomy". Therefore, he proved to be paying attention to the peculiarities that separated the dancing events in elegant neighborhoods from those of the suburbs and poor regions. In Botafogo, dancing would be "calm and majestic as a religious rite", with "harsh gentlemen" wearing black coats and white ties. At the same time, in Saúde, these dancing traditions originating from Europe would clearly blend with other musical influences, which were absent, in refined balls:

In Saúde, the Dance is a fusion of dances, the samba - a mixture of the African jongo and batuques, the Portuguese canaverde, the Indigenous poracé. The three races blend together in the samba, as in a melting pot. Samba is the opoplocia of the slum, it is the pirrica of the inn. [...] In it, there is no more racial conflict. In it, the hates of color are absorbed. Samba is - if you let me say so a type of teapot, in which, separately, there are dark coffee and white milk, and from where comes out, homogeneous and harmonic, the hybrid coffee milk.

As opposed to the European notion of the dancing ballrooms in the richer neighborhoods, the signal of the balls organized in the neighborhood of Anjos da Meia Noite would be the strength of the supposedly African or indigenous dancing habits. This uniqueness, at the same time, marked the connection of the balls in Saúde with the more general phenomenon throughout the city, and such uniqueness was created by this particular cultural signature. As a result, the small ballrooms of the neighborhood formed a type of strong and original dance, which no longer blended with particular dancing traditions from which it had been created.

${ }^{22}$ Cf. "Carnaval - Os clubes e grupos licenciados", Gazeta de Notícias, 10 de fevereiro de 1906; e Arquivo Nacional, GIFI 6C 377.

${ }^{23}$ Fantasio (Olavo Bilac), "A dança no Rio de Janeiro", Kosmos, Ano 3, n. 5, Maio de 1906. 
However, Bilac talked about a socially determined phenomenon. He points to the harmonic mixture of traditions as a way to overcome the "hates of color" in the neighborhood. He is aware that, at that point, such a process belonged to a very limited social group, which was present in the life of the neighborhood: the low-income workers, who lived in slums and inns, and many of those were in Saúde. They would see the samba as the characteristic dance with which it was possible to fight their opponents, such as the opoclocia or the pirrica of the Greeks. ${ }^{24}$ The chronicler approached the rhythms of the balls in the neighborhood as the phenomenon connected with the world of the workers in Saúde, which was able to define their identity.

\section{While the samba had its "origins in the dances of countryside of Central Africa", the ball would be "much softer", "dancing slowly, accompanied by the sound of a piccolo and cavaquinho"}

Therefore, the mention of these combat dances did not seem to be casual in the chronicle of Bilac. By referring to the way the poor workers in Saúde danced, Bilac could be thinking about the common social and cultural disputes resulting from the shock generated between their costumes and practices, and the behaviors expected from such shock by some of the ideologists of the new Republican nation. It is likely that Bilac witnessed this reality, tragically, less than two years earlier, at the time of the Vaccine Rebellion. At the time, the Street Camerino, where the office of Anjos de Meia Noite was located, was in trenches formed by "bags of sand, cobblestones, and pieces of wood". Behind them, the workers of the neighborhood defended their traditional healing practices as they could, since they were threatened by the mandatory vaccination project. ${ }^{25}$ Possibly by reminiscing about the episode, Bilac saw the samba in the balls of Saúde as a cultural habit, which was able to establish a well-defined identity for the workers in the neighborhood, as a sense of danger seemed to be always present.

The reference Bilac makes to the specific nature of Saúde would be clearly understood by any contemporary. Despite the unexpected citation of indigenous dances, the region of Saúde was known, at the time, for the strong presence of the Black and Mulatto workers. Established around the port, the

${ }^{24}$ Opoplocia and pírrica are military dances from Ancient Greece. Cf. Encyclopédie militaire et maritime par le Comte de Chesnel, vol. 1. Paris, Le Chevalier, 1864 ; e G. Desrat, Dictionnaire de ladanse, historique, théorique, pratique et bibliographique, Paris, Imprimeries Réunies, 1895, p. 260.

${ }^{25 " A}$ revolta dos alunos militares - Gravíssimo - Os fatos de ontem - Na Saúde", Gazeta de Notícias, 15 de novembro de 1904. About the connection between the rebellion and the strength of African cultural heritage in the neighborhood, see Leonardo Pereira, Barricadas da Saúde. Vacina e protesto popular no Rio de Janeiro da Primeira República, São Paulo, Perseu Abramo, 2002. 
neighborhoods of Saúde and Gamboa had a lot of dockworkers - and in such professions, there were many workers with African ascendancy. Despite the massive arrival of European immigrants to the city since the last decades of the $19^{\text {th }}$ century, the port still had mostly national workers. For that reason, there was "a strong continuity between the men who were enslaved and those who were free in the old Empire times, and the workers of the early period of the Republican system". ${ }^{26}$

So, not by chance, in that region there was frequent news about batuques and candomblés (Afro-Brazilian religions). The belief in the orixás (representations of God in the Afro-Brazilian religions) was not restricted to a specific neighborhood, since it could be observed all over the city, but its main location was that region. In 1886, Mother Aninha founded her terreiro (places where the religious rites took place) and initiated a proliferation of such institutions in the region. ${ }^{27}$ In a chronicle published in 1904, in the newspaper, Gazeta de Notícias, about the religious practices in Rio de Janeiro, João do Rio names several other terreiros who were located in that region..$^{28}$ It is true that the port zone also had other groups of immigrants or poor White residents, but the intense presence of this type of manifestation of African costumes and habits was one of its main signatures.

Together with the religious manifestations, there were festivals and dancing practices in the region, associated by the contemporaries themselves to the African heritage. On December 20, 1886, a paid note published in the newspaper $O$ Paiz called the attention of the police to a house at the back of an inn, "where there are major batuques, which bother the neighbors and continue until much later than 10 o'clock at night".29 Even if forbidden by the Municipal Code, "batuques and tocatas of the Blacks", were common around that region, which involved the neighborhoods of Saúde, Santana and Gamboa, as the accusation presented by a fiscal to the Municipal Chamber in 1886 demonstrated. ${ }^{30}$ Called batuques (the word also means drumbeats), due to the importance of the use of percussion instruments, such parties were seen as a frequent leisure option for the inhabitants of the region of Saúde in the second half of the $19^{\text {th }}$ century.

However, something had changed in the early years of the Republican system. In the last decades of the Empire those practices were seen by the Delegate of the District of Santana as "very old and always tolerated by all of the Chiefs of police and sub-delegates", but the control and surveillance of the Republican police would hit them much harder. Such attempts to control them led to a process of institutionalizing these celebrations, and their

\footnotetext{
${ }^{26}$ See Maria Cecília Velasco e Cruz, “Tradições negras na formação de um sindicato: Sociedade de Resistência dos trabalhadores em Trapiche e Café, Rio de janeiro, 1905-1930", Afro-Ásia, n. 24, 2000, p. 243-290. In the article, the author demonstrates that, from 1890 to 1904, blacks and mestizos constitued 60.5\% of the dockworkers in prison.

${ }^{27}$ See Agenor Miranda Rocha, As nações Kêtu: Origens, ritos e crenças. Os candomblés antigos do Rio de Janeiro, Rio de Janeiro, Mauad, 2000, p. 25.

${ }^{28}$ The report by João do Rio, originally published in Gazeta de Notícias in 1904, was present in the following year in the book As religiões do Rio, Rio de Janeiro, Organizações Simões, 1951 (1905).

29"A Polícia”, O Paiz, 20 de dezembro de 1886.

${ }^{30}$ Arquivo Geral da Cidade do Rio de Janeiro, "Diversões particulares. Pedidos de licença (1833-1908)", 42.3.14.
} 


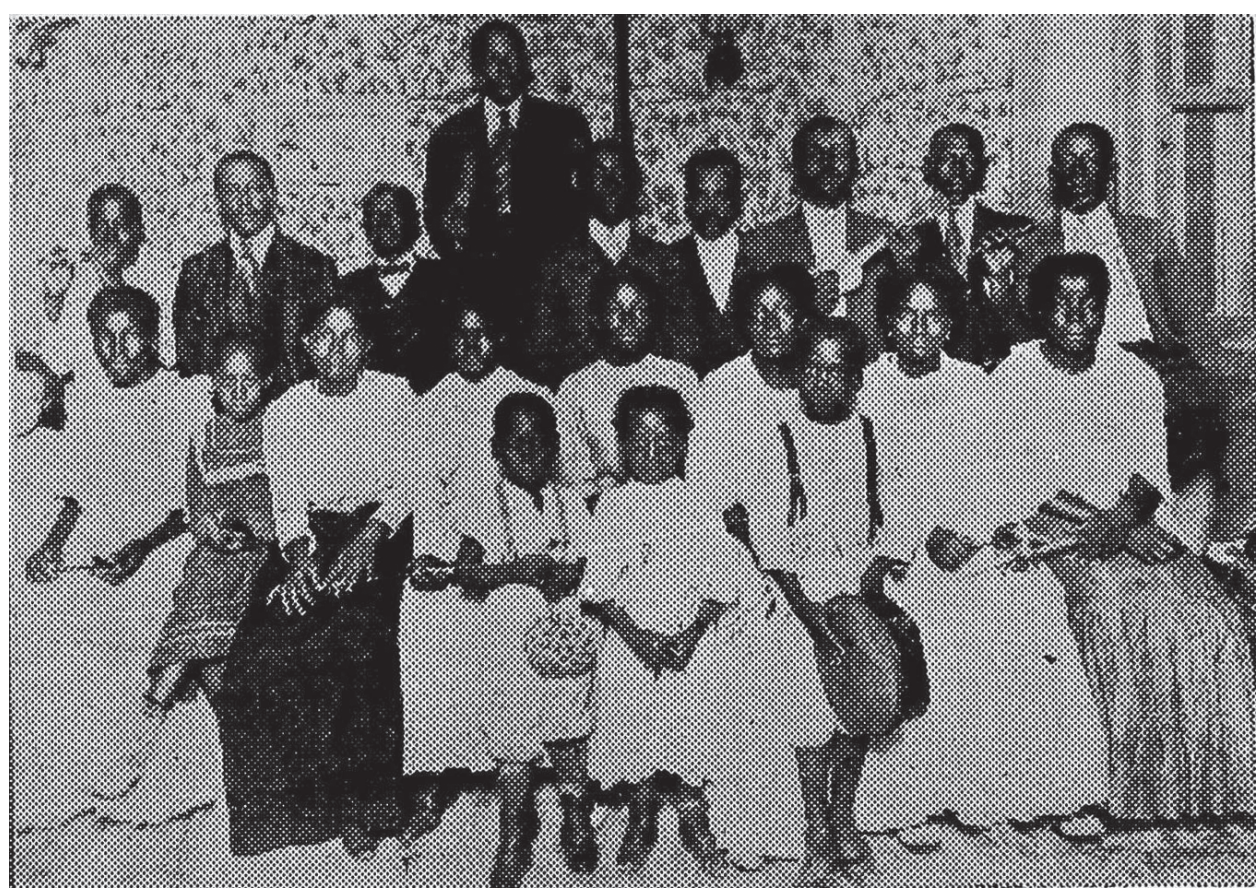

"O Macaco é Outro" (REVISTA DA SEMANA 18 de fevereiro de 1911),

carnival group.

promoters tried to escape police persecution by obtaining licenses of operation granted to dancing and carnival clubs. This process began in 1886, when "Club da Saúde" was founded. Defined by the newspaper as a "modest and distinct society", it aimed at promoting monthly balls to its associates. ${ }^{31}$ The success of this model led to the creation of several similar clubs in the neighborhood, starting in the early years of the Republican system. Rei de Ouros (King of Golds) was founded in the neighborhood Pedra do Sal in 1894 by a group of Blacks from Bahia, and its headquarters was located in Morro da Conceição; the Prazer da Providência (Pleasure of the Providence), which got a license of operation in the next year, and Sociedade Dançante Carnavalesca Jardineira (Jardineira Carnival Dancing Society). ${ }^{32}$

Although having different colors, songs and headquarters, these dancing societies were similar in their composition and recreational logic. The latter is expressed clearly in one of them, called Rosa Branca (the white rose), located on the street of Cajueiros. In a chronicle published in the carnival of 1905, João do Rio talks about being approached by one of its components, whom he had known for a long time, to get "a license" for the club. ${ }^{33}$ Besides demonstrating the importance of the license of operation for these societies, this situation led the chronicler to visit the mentioned club. On that day there would be a

${ }^{31} \mathrm{Cf}$. O Paiz, 17 de julho de 1886 e 21 de maio de 1887.

${ }^{32}$ Cf. Nireu Cavalcanti, “Memórias de alegria: O Rio de Janeiro na folia dos ranchos (1893-1911)", In: IcléiaThiesenet al., Vozes do Porto: memória e história oral, Rio de Janeiro, DPA/Unirio, 2005, p. 93; O Paiz, 24 de fevereiro de 1895; e Jota Efegê, Ameno Resedá, o rancho que foi escola, Rio de Janeiro, Letras e Artes, 1965, p. 76-81

33João do Rio, "Afoché", Gazeta de Notícias, 2 de março de 1905. 
carnival rehearsal with "a soiree and samba in the back room". After entering the modest rooms of the club, he heard the dances and songs "accompanied by tambourines and atabaques". He was impressed by the administration of the club, and its board which cared for the organization of the celebrations. "It is common that these important positions be taken by witchcraft assistants", he comments, by stating the proximity between the religious and festive practices of these workers with African ascendancy. Even if the club members may not always talk about the dancing activities from those related to carnival or religion, the informer of the chronicler explains to him that "the license is always requested for a dancing society", and the legitimacy of this institution was certified by chronicles such as the ones by Olavo Bilac.

With that, the club became a legitimate place to express the costumes and practices shared by its associates, which could be exposed in different ways and in different spaces. "Those who want to dance the samba can go to the back, and those who like balls stays in front", explained the chronicler. The difference between the two spaces was clear for the chronicler: while the samba had its "origins in the dances of countryside of Central Africa", the ball would be "much softer", "dancing slowly, accompanied by the sound of a piccolo and cavaquinho" - with a sort of music that even had some signs of African origin. However, it was seen by the members of the club as a clear blend between this and other musical forms coming from Europe. Therefore, "the Blacks and Mulattos" he saw at the club had their own space for entertainment in that type of association, in which they both tried to legitimate their habitual practices and tried to blend them to new trends and influences that began to be theirs.

The connection of many of these small neighborhood clubs was not only social, but also ethnical. As much as Saúde was far from being any kind of territory that was exclusively for the Blacks, since there were many workers from other origins and with different ethnical profiles, ${ }^{34}$ the model adopted by clubs like that was based on sharing and defending some identity symbols related to Africa. At least this is what was suggested in 1914, by the dispute that would separate the associates of Heróis Brasileiros (Brazilian Heroes), which had been working in Gamboa since 1900, from those of Retiro da América (America's refuge), founded in Saúde in $1888 .{ }^{35}$ In the carnival of 1914, some of the associates of the latter group sent some verses to the newspaper A Época, called "Sentido Negrada", which expose their differences with the rival. By suggesting to have received a "banana bunch" from the club, which had an openly racist reference to the color of its components, they responded to the "mondrongos of Heróis" (that is, to the clumsy components of the rival club) in the same tone. "Heroes, how sloppy of you/you are not Brazilian". They sang and suggested the falsehood of the name they tried to sustain for themselves. "Poor aristocrats, they all end up in the asylum", concluded the members of Retiro da América, by trying

\footnotetext{
${ }^{34}$ According to the census of 1906 conducted in the Federal District, the district of Santa Rita, in which Saúde was located, counted, at the time, on 38.28\% of the foreign inhabitants. See Recenseamento do Rio de Janeiro realizado em 20 de setembro de 1906, Oficina da Estatística, Rio de Janeiro, 1907, p. 123.

${ }^{35}$ See Arquivo Nacional, IJ6 692; e A Época, 17 de janeiro de 1913
} 
to associate the color of their skin to the signature of nationality. ${ }^{36}$ Workers like those who composed Retiro da América were articulated by trying to express the strength and the pride of their identity like that.

This logic would trigger the major boom of dancing associations in Saúde that can be observed in the early $20^{\text {th }}$ century — with that, more than 15 clubs of the type could be found in the neighborhood in the year of $1913 .{ }^{37}$ Among them, Anjos da Noite was present since 1906, and in the following year it tried to secure its legitimacy by requesting the annual license of operation to the Chief of Police. ${ }^{38}$ After appropriating the title of a very popular theater play in Rio de Janeiro in the early $20^{\text {th }}$ century, whose success was a result of the appreciation it received from the low income audience due to the scenic tricks and gaudy scripts, ${ }^{39}$ the associates of the club gave their first indication about its composition. It would be certified by the list of its founders and directors - among which, in 1908, was the dockworker Leonardo Machado, who presented himself as its vice-president. ${ }^{40}$ Formed by low income workers such as him in a neighborhood that was mostly inhabited by the Blacks and Mulattos, the club represented another leisure space formed by these people in that time.

Therefore, at the crossroads of habitual practices and elegant trends, such as the dancing fever, that the members of clubs like Anjos da Meia Noite tried to secure their space and legitimacy in the early period of the Republican System which placed them as part of that movement to create an identity for the neighborhood, identified by Bilac months before its foundation. By this route, in the early years of the $20^{\text {th }}$ century, the associates could see some identity signals, with strong traces of the Black traditions that were recognized by the chronicler and his readers. What would be the consequences of this symbolic operation was yet to be understood.

\section{The process of citizenship}

From the moment these small clubs in Saúde adopted the Black and "Mestizo" image that was projected by the chronicle of Bilac, its path towards affirmation could not have been easier. Even if they were formally organized to escape police persecution, sometimes these associations could not reach that objective. With its regular operation supposedly ensured by the annual license, they had to live with the threat of its annulment by the police, which would prevent their activities from continuing. This possibility was present during the entire period of existence of these small clubs, but in the early 1910s the tension

36"C.C. Retiro da América”, A Época, 20 de fevereiro de 1914.

${ }^{37}$ Arquivo Nacional, GIFI 6C 432.

${ }^{38}$ Arquivo Nacional, GIFI 6C 213.

39"Teatro Recreio", Correio da Manhã, 20 de outubro de 1902. About the popularity of the dance and its reasons, see João Roberto Faria, "Machado de Assis - tradutor de teatro", Machado de Assis em linha, ano 3 , n. 6, dez. 2010, p. 56.

40See "Vida Operária”, Correio da Manhã, 27 de março de 1906. 
between the police in that district and the small recreational societies seemed to have become deeper.

The associates of Anjos de Meia Noite would witness this type of a posture change. After functioning regularly in its formative years of activity, they were surprised on January 2, 1910, due to a request sent to the Chief of Police by the district Delegate, Benedicto da Costa Ribeiro. He requested that the "license for this society to function" should no longer be granted due to its composition, "since it is the meeting point of low-class strumpets, vandals and thieves". As a result, the Chief of Police decided that "no license would be granted for the operation of this society." ${ }^{11}$ Though the license had been provided with no obstacles, from that moment on, the social aspect of the club was under suspicion, since it was formed by the members of the so-called "dangerous classes". ${ }^{2}$

The following years would demonstrate that it did not happen by chance. In a systematic way, dancing clubs in Saúde and other neighborhoods inhabited by workers started to face similar situations, and several police authorities started to suspect them, trying to put obstacles and prevent their free operations. When the carnival society Triunfo dos Beija Flores (Triumph of the Humming Birds), whose headquarters was located in Morro da Providência, requested its license of operation in February, 1912, to the Chief of Police, its associates were victims of the same logic that had hit the members of Anjos da Meia Noite. Before the suit could go to the respective district, Arthur Rodrigues da Silva, Security Inspector, was to provide the first report about these requests, and he informed that "this society was composed of vandals and bums, and there was no one that could endorse their conduct". After his opinion was received, the Delegate of the district forwarded the case to one of his Commissioners, who had another point of view: after meeting with the components of the club, he thought it was composed by "men with honest jobs and fixed residence, so there was no inconvenience in approving its statutes and grant the license it requires." The suit then returned to the Security inspector, who once again accused the "president of this society" of being "a deserter of the Police Force", who had been arrested for that. The club's member, who had declared to be "an employee of the warehouse of the Central Station", would only go there "once or twice a month", so it was not possible to "say he had a job". The second member, on the other hand, had been fired from his job in the loading department of Leopoldina Railway "for being a lay about" - as well as the club's attorney, who was fired "for being caught stealing wine from a barrel in the deposit". ${ }^{43}$ Persecuted for the poor and unstable character of the labor relations established by its associates, the club had to let them go in order to get the police license, thus adjusting to the rules of the official control.

\footnotetext{
${ }^{41}$ Arquivo Nacional, GIFI 6C 367.

${ }^{42}$ About the association between the "poor" and the "dangerous classes" in Rio de Janeiro back then, see Sidney Chalhoub, Cidade febril: cortiços e epidemias na Corte Imperial, São Paulo, Companhia das Letras, 1996.

${ }^{43}$ Arquivo Nacional, Documentação de Polícia, p. 416, cx. 5553.
} 
There were many cases like this in the neighborhood, ${ }^{44}$ showing that the social profile of the members of the clubs justified the persecution of police authorities. The differentiation made by the police between clubs due to their social profile was perceptible, even for contemporaries. In a note of 1916, about the constant "conflicts in fancy game clubs", a writer of the newspaper A Noite mentions that "if they were small clubs, they would be battered, the board would go to jail and the license would be annulled", things that rarely happened in elegant clubs. ${ }^{45}$ The license annulment faced by Anjos da Meia Noite in 1910 was the beginning of a repression against small dancing clubs formed by workers, and with that the police tried to control the increasing number of associations that were observed in neighborhoods like Saúde.

Without accepting the role of victims of the police action, the associates of Anjos da Noite began an elaborate reaction strategy to secure the working of the club. It consisted firstly on an attempt to revert the decision, in order to recover the license of operation. For that, the club formally excluded the "old associates with unreliable conduct", who were found to be the justification for the license to be denied, as the local police Commissioner stated in 1912. "It is also worth to mention that many associates have an identity card", concluded the Commissioner, pointing out that "employees of the commerce, artists, workers of the pier and the port police" who composed the club would then have "known residence and profession". As a result, the club could recover its license in April, 1912, despite the report of the Security inspector. ${ }^{46}$

Besides that immediate reaction, the associates of the club also tried to avoid the recurrence of such incidents more permanently. Therefore, in March, 1910, they decided to register their statutes in the civil registry, also publishing part of it in the Official Journal, ${ }^{47}$ even if it was not necessary for recreational clubs such as Anjos da Meia Noite. By doing that, they were supported by a law approved in 1893 to regulate "the organization of associations that were founded for religious, moral, scientific, artistic, political or recreational purposes". In its first articles, the law stipulated that the associations created with such ends could "acquire legal individuality" by registering its social contract or statutes in the "civil registry of the region where the headquarters is established". 48 The result was that such associations would have "legal validity, as distinct persons from their respective members, being able to exercise all of the civil rights related to the interests of their institute". Opposing the judgment of the police officers, the associates of Anjos da Noite looked into the Republican legislation for a guarantee to regulate its functioning, something that did not depend on the

\footnotetext{
${ }^{44}$ Check the cases of Triunfo dos Beija-Flores, which would be composed of "unemployed people, bums and vandals" and Couraceiros do Inferno, "attended by the social scum". This is why the local delegate wanted to shut them down "as an initiative of social order", Arquivo Nacional,GIFI 6C 479 e Documentação de Polícia, P. 489, cx. 5668.

${ }_{45}^{45}$ O conflito no Palace Club", A Noite, 29 de outubro de 1916

${ }^{46}$ Arquivo Nacional, GIFI 6C 367.

47"Sociedades civis - Club Dançante Familiar Anjos da meia Noite”, Diário Oficial, 10 de março de 1910, p. 1786

48“Lei no 173, de 10 de setembro de 1893", Available from: <http://www2.camara.leg.br/legin/fed/lei/1824-1899/ lei-173-10-setembro-1893-540973-publicacaooriginal-42519-pl.html>. Cited: 5 Feb. 2013.
} 
opinion of the Delegates or Inspectors about its associates. Therefore, it was clearly a legal strategy and, at the same time, a political action: the guarantee of freedom to manifest its own practices and costumes, expressed in the daily activities of the club.

\section{The members of several other clubs in the port region also articulated the dancing associations to the political struggle in their experiences.}

At the first sight, it may be surprising that the low income workers who composed the club, whose objective was merely recreational, were so careful about the legal gaps that could help to build its legitimacy. However, it is enough to take a closer look over its components. Far from the alienated and passive image, projected by many militant workers in the period, about the components of these clubs like that, ${ }^{49}$ the associates of Anjos da Noite did not see the contradiction between the search for leisure and the more effective participation in the social and political disputes. Not by chance, one of its founders was the stoker David Francisco Candido, who had been an active participant of the General Central of Stokers since 1904 and, in 1912, he was even more involved with the proposals of "class unions". ${ }^{50}$ Likewise, when the club decided to make its statutes official, the president was the dockworker Leonardo Machado, who had been an active participant of the Union of Dockworkers since 1906 - and this society was in the same Largo do Depósito, where its headquarters was located, and Leonardo joined the board from 1908 on..$^{51}$ As category leaders with strong presence of the Blacks, these individuals proved that, for parts of the workers' movement that were far away from the model of political action that was common with the European immigrants, the search for leisure and political action seemed to be articulated in the same experience, and this was far from being defined by alienation. The problems of the associates of Anjos da Meia Noite were not an isolated case. Like them, the members of several other clubs in the port region also articulated the dancing associations to the political struggle in their experiences. In September, 1906, after deciding to found the Society Union of the Stokers to fight for their rights, the workers looked for a shelter exactly in the headquarters of Retiro da América. ${ }^{52}$ In the case of Anjos da Noite, however, these connections seemed to be even clearer. In the end of 1912, when Leonardo Machado left the presidency of the club, Victorino Gonçalves took

\footnotetext{
${ }^{49}$ See Leonardo Pereira, "The Flower of the Union: Leisure, race and social identity in Bangu, Rio de Janeiro (1904-1933)", Journal of Social History, vol. 46, n. 1, fall 2012, p. 154-169.

50See "Vida operária", Correio da Manhã, 29 de março de 1904 e "Coluna operária", A Época, 9 de dezembro de 1912.

51“Vida operária”, Correio da Manhã, 27 de março de 1906 e 2 de setembro de 1908.

${ }^{52}$ See "Sociedade União dos Foguistas", A Época, 27 de setembro de 1917. About the composition and headquarters of Retiro da América in 1912, see Arquivo Nacional, GIFI 6C 367.
} 
over, and he was described by the police Commissioner as a dockworker "who had good reputation for loving his work and for his conduct".53 Like Leonardo, he actively participated in the workers' movement in Rio de Janeiro, especially in the Workers' league of the Federal District, where he became the president in 1913. ${ }^{54}$ Though he could have had political or administrative differences with the former president, ${ }^{55}$ he shared the same perspectives in relation to dancing associations, and their importance was not put aside in favor of other spaces of social articulation that could be supposedly more relevant.

Therefore, it was not strange that the associates of Anjos da Noite were so attentive, in 1910, to the political meaning of the annulment of their license. To avoid it, they elaborated a strategy that showed that there was no essential difference between a recreational association and another one, with political or union aspects - hence trying to secure the former would function by the same rules and laws that support the latter.

This was the logic that would be exposed after May, 1913, when a minor conflict in the club worked as a pretext for the new attempt of the Chief of Police to stop its operation. On a Saturday night, May 24, Anjos da Meia Noite threw, as usual, their famous ball. In the balls at its headquarters, filled with people, the associates and other guests danced happily in pairs, to the sound of choros and polkas played by a "charanga" ${ }^{56}$ Among them, there were Henrique Rodrigues da Fonseca, a tile layer who was then the second fiscal of the club, ${ }^{57}$ and a man named Joaquim Barbosa, his copartner, who was defined by the reporter of Jornal do Brasil as "Mulatto" ${ }^{58}$ With no respect for the behavioral rules established by the statutes of the clubs, Barbosa insistently harassed a woman, who would be the date of Henrique throughout the night. Such harassment bothered Henrique, who confronted the womanizer, and then the misunderstanding began. At first, it was controlled by the intervention of the Director of the club, who told them it was not allowed to "discuss inside the ballroom". The case continued up to four a.m., when the ball was almost in the end. After they left the club, they met again at Largo do Depósito, where their headquarters was located. The result was a physical confrontation which ended up with a gunshot that hit Joaquim Barbosa in the leg. Henrique, in the end, was also wounded when he attempted to escape. ${ }^{59}$

Facing this situation, the board of the club immediately argued that the misunderstanding had nothing to do with the ball, or that the crime had been

\footnotetext{
53Arquivo Nacional, GIFI 6C 367.

54"Coluna Operária", A Época, 3 de março de 1913 e 24 de abril de 1913.

${ }^{55}$ In a paid note published in Jornal do Brasil, on May 17, 1913, to announce one of his balls, Victorino Gonçalves required the "former president" of the club that, in five days, he could show up to "state his incomes, as verbally promised", and, by the end of this period, "his name would be published in the papers" "S.D. Anjos da Meia Noite", Jornal do Brasil, 17 de maio de 1913.

56"Tentativa de assassinato", O Imparcial, 26 de maio de 1913.

${ }^{57}$ This is the statement in the request for the license forwarded to the police by the club in 1912. Arquivo Nacional, GIFI 6C 432; e "S.D. Anjos da Meia Noite", Jornal do Brasil, 17 de maio de 1913.

58“"Quem não trouxe... - Depois do baile - Ciúme sanguinário", Jornal do Brasil, 26 de maio de 1913.

59“Um turumbamba no Anjo da Meia Noite”, O Paiz, 26 de maio de 1913. Even if different in some points, News about the conflict can be seen in "Tentativa de morte", A Epoca, 26 de maio de 1913; "Na sede do Club Anjo da Meia Noite", Correio da Manhã, 26 de maio de 1913.
} 
triggered in their headquarters, outside the club. After showing up spontaneously to the office of Jornal do Brasil to clarify the situation, Deocleciano Silva, First Secretary of the association, explained that "the ball ended at 3:40 a.m., and the conflict took place at 4:50 a.m., that is, almost one hour after the club was closed". He also stated that the "mess happened in the street, and during the ball there was not the slightest chance of disorder" ${ }^{60}$ However, such explanations served no purpose. Facing the major coverage of the case by the press in the federal capital, the Chief of Police issued an order to annul the license of operation of the society to the District Delegate, thus determining the "closure of the social headquarters" and "preventing, by means of his agents of public force" the club from operating. ${ }^{61}$

\section{These workers turned their dancing practices into ways to fight for their freedom and their rights, in favor of the Republic they wanted}

The first reaction of the board, right after they heard "through the Delegate of the $2^{\text {nd }}$ Police District and newspaper news published in this capital" about the determination to shut down the club, they wrote, on June 5 , to the $2^{\text {nd }}$ Assistant Delegate who was in charge of public entertainment, requesting that the "aforementioned order" could be revised.$^{62}$ On the next day, the Assistant Delegate sent a short response to such request - "address those who should be addressed" - suggesting that such request should be forwarded to the Chief of Police, Edwiges de Queiroz. And so, the president of the club does so on the $7^{\text {th }}$ of that month, in an official report, reproducing the same argument that had been presented to his assistant. It explained that the "associations are subject to the supervision and license of the police [...] only those that do not have legal personality", and that was no longer the case of Anjos da Meia Noite. Because of such illegality, they appealed to the Chief of Police to "revise the aforementioned order, so as to avoid the legal solutions that could be used in this case." ${ }^{\prime 3}$

The final dismissal of the request by the Chief of Police, issued on June, 14, led the associates of the club to fulfill the promise expressed at the end of the petition, looking to repair the situation legally. And so they did a few days later, on June 20, in the request of habeas corpus originally sent to the Court of Appeal.

Again, they complained about the "violent, arbitrary and abusive act of power by the Chief of Police", who would find no support in the "dispositions

60"Quem não trouxe...", Jornal do Brasil, 27 de maio de 1913.

${ }^{61}$ Arquivo Nacional. Fundo Supremo Tribunal Federal (BV). BV.4624. - Série Habeas Corpus - Clube Dançante Familiar Anjos da Meia Noite (1913), fl. 2.

62/dem, Ibidem, fl. 6

63/dem, Ibidem, fl. 5 
of regulations and preventive warning of the police concerning the operation of civil associations" who had legal personality, as was the case of Anjos da Meia Noite. Besides that, they argued a bit more. Appealing to paragraph 8, article 72 of the Republican Constitution - which established that "it is licit to all to associate and gather freely and without guns; in such case the police cannot intervene, except to keep public order" - they claimed to have the right of "any civil association" to be "free of police abuse and violence concerning its free operation, regardless of the license to exercise the purposes of the institute". For that reason, they requested the habeas corpus in favor of the club so that it could

freely exercise all of the civil rights inherent to the interests of its purpose, as established by the law [...] regardless of any license from the police and no disturbance or coercion of any kind from any police authority and its agents. ${ }^{64}$

Once again, however, the expectations of the associates of the club were frustrated. For technical matters, the Court of Appeal claimed that the "appeal was unreasonable", and "did not know of the judged request". ${ }^{65}$ Hence, as a final attempt to maintain their aspirations, the associates of the club appealed, on June 20, to the venerable "Federal Supreme Court", which should have "rightfully, with jurisprudence", the courage to secure the associates of clubs such as Anjos da Noite with their rights, as opposed to the omission of the other spheres of justice. So, it would be up to the Supreme Court, with this logic, to cease the "illegal embarrassment to which the Family Dancing Club Anjos da Noite had been submitted to". To support such request, they also appealed to the determinations of the law that regulated the institute of a habeas corpus, from 1871 - especially one of its articles, which defines that the authority that recognizes the "illegal embarrassment, abuse of authority or violation of the law" can "order or request the responsibility of the one that abused". ${ }^{66}$ Besides the concession of the habeas corpus, the associates of the club also charged the Federal Supreme Court with the punishment of the Chief of Police who was in charge for the judgment, in order to reestablish the Constitutional principles of the Republican order.

As the strategy adopted by the associates of Anjos da Meia Noite since 1910 to escape police persecution, the arguments were presented by the club to request the habeas corpus and exposed the political sphere of its action. At a time when the workers of Rio de Janeiro began to regularly appeal to the Supreme Court to ensure their rights, ${ }^{67}$ the associates of the club showed the broad meaning attributed to their request, which was far from solving the specific problem that originated it. From their point of view, the

\footnotetext{
${ }^{64}$ Arquivo Nacional. Fundo Supremo Tribunal Federal (BV). BV.4624. - Série Habeas Corpus - Clube Dançante Familiar Anjos da Meia Noite (1913), fl. 2.

65/dem, Ibidem, fl. 7; e "Justiça local - Corte de Apelação", O Paiz, 22 de junho de 1913.

66/dem, Ibidem, fl. 12.

${ }^{67}$ About that, see Gladys Sabina Ribeiro, "Cidadania e luta por direitos na Primeira República: analisandoprocessos da Justiça Federal e do Supremo Tribunal Federal", Tempo, n. 26, jan. 2009, p. 101-117.
} 
certainty that the club could continue with its activities was connected to the 'search of rights' desired by the workers, such as the one who was part of the club, expressed in the possibility of continuing to practice their dancing habits.

The police commits all of these abuses, illegalities, and forgets about the fact that, constitutionally, nobody can be obliged to do or not to do anything other than activities regulated by the law,

said their lawyer in the appeal delivered to the Court of Appeal. ${ }^{68}$ Therefore, using the gaps of the legislation, which was created to ensure and perpetuate their exclusion - as occurred in the previous century, when many of their ancestors who tried to look for gaps inside a pro-slavery society, ${ }^{69}$ these workers turned their dancing practices into ways to fight for their freedom and their rights, in favor of the Republic they wanted.

However, this struggle was difficult and long, far from being over. Facing the arguments of the club's lawyer, the judges of the Supreme Court chose to "turn the trial into diligence, and requested information from the Chief of Police in this District about the claim in the referred petition". He answered a few days later, confirming to have annulled the license after the request of the District Delegate. Besides mentioning the conflict that took place on May 25, he said the club was the "meeting point for dangerous and evil individuals, who charged an entrance fee for dancing without being allowed to do so". Although he did not present any evidence to support his claims, they were accepted by the judges of the Supreme Court. Without facing the central point of the argument in the request, they decided to deny the appeal by claiming that the habeas corpus would aim at "ensuring the individual freedom", therefore, it could not be valid for a dancing club. Even if the appeal was acceptable, however, the decision of the court states that the "provided information demonstrates that the police authority worked within the sphere of its legal attributions", therefore, the concession of the appeal was not justified. ${ }^{70}$

At first sight, the result of the suit showed that the appeal was not an effective way for the associates of Anjos da Meia Noite to accomplish their rights. At that time, the road taken by similar associations who were trying to secure their survival within the aspects of paternalism was more effective, and they brought to their board traders and authorities of the neighborhoods where they were formed, thus getting protection from police judgment. ${ }^{71}$ Still, the struggle waged by the members of the club demonstrated that the workers

\footnotetext{
${ }^{68}$ Arquivo Nacional. Fundo Supremo Tribunal Federal (BV). BV.4624. - Série Habeas Corpus - Clube Dançante Familiar Anjos da Meia Noite (1913), fl. 3.

${ }^{69}$ See Elciene Azevedo, O direito dos escravos: Lutas jurídicas e abolicionismo na província de São Paulo, Campinas, Ed. da Unicamp, 2010. Also check in similar perspective, E.P. Thompson. Senhores e caçadores. A origem da Lei Negra, Rio de Janeiro, Paz e Terra, 1987 [1975].

${ }^{70}$ Arquivo Nacional. Fundo Supremo Tribunal Federal (BV). BV.4624. - Série Habeas Corpus - Clube Dançante Familiar Anjos da Meia Noite (1913), fls. 16-18.

${ }^{71}$ See Leonardo A. de M. Pereira, "E o Rio dançou. Identidades e tensões nos clubes recreativos cariocas (1912-1922)", In: Maria Clementina Cunha (org.), Carnavais e outras f(r)estas, Campinas, Ed. da Unicamp, 2002, p. 419-444.
} 
who formed it were paying attention to the possibilities of freedom and autonomy inside the new Republican Order. After being placed in a juridical system that is made to exclude them, these individuals tried to find their own methods to conquer space. After making the judges of the Federal Supreme Court expose the contradictions of the constitutional order created by the Republic, they helped to expose the arbitrariness of the political system - thus contributing to weaken its ideological bases. Therefore, it was harder for the police to repress the operation of such associations - especially when their associates added the fight for their rights to the search for support and legitimacy of the local White traders.

Hence, the case lights up the political logic that existed as usual forms of association for many Black and Mestizo workers of the time. By acting with their own forms of struggle for their rights, which was already common for people like them since the Empire - when the slaves took their spaces of leisure to affirm and exercise their identity bonds, turning the practices of their daily lives into their own form of struggle against the domination to which they were submitted,$-{ }^{72}$ the members of the club tried to articulate them to new values and logic that were learned from the ideologists of new Republican times. Therefore, they showed the dynamic character of their struggle, which was far from being over with a simple appeal to the tradition. In this way, the limits of a memory that tried to turn them into passive victims of the radial and political speeches that served as a base for the ideologists of the Republic became clear.

\footnotetext{
${ }^{72}$ See, for instance, Robert Slenes, '“Eu venho de muito longe, eu venho cavando': jongueiros cumba na senzala centro-africana”, In: Silvia Hunold Lara; Gustavo Pacheco (orgs.). Memória do jongo: as gravações históricas de Stanley Stein, Rio de Janeiro, Folha Seca, 2008, p. 109-156.
} 